\title{
EFFECT OF CULTURE MEDIUM IN CALLOGENESIS FROM ADULT WALNUT LEAVES (Juglans regia L.)
}

\author{
Fabiola Avilés ${ }^{1 *}$, Darcy Ríos ${ }^{1}$, Ricardo González ${ }^{1}$, and Manuel Sánchez-Olate ${ }^{1}$
}

\begin{abstract}
To define preliminary aspects of walnut (Juglans regia L.) callogenesis in indirect propagation systems, this work analyzed callogenic induction in adult leaves of walnut in broadleaf trees (BTM), Murashige and Skoog (MS) Driver Kuniyuki Walnut (DKW) and Woody Plant (WPM) media. Leaf segments of $1 \mathrm{~cm}^{2}$, previously sterilized, were placed in each culture medium, supplemented with $21.4 \mu \mathrm{M}$ naphtalene acetic acid (NAA) and $8.8 \mu \mathrm{M}$ 6-benzylaminopurine (BAP). A completely random design was used; the experimental unit was a Petri dish with six callus explants. Each treatment was composed of seven Petri dishes. Callogenesis (\%), nodular calli (\%) and histology of calli explants were evaluated at 4 weeks by staining $10 \mu \mathrm{m}$ slices with safranine-fastgreen. There were no significant differences $(\alpha=0.05)$ in callogenesis among evaluated media; but nodular calli percentages were significantly higher in BTM (75\%) and WPM (63\%). Only in calli obtained in the BTM medium did the histology show the presence of meristematic zones, but without external expression. These results indicate that the medium influences the morphogenic characteristics of resultant callus. Calli produced in BTM presented better morphogenic potential, with meristems at primary stages of organization.
\end{abstract}

Key words: auxins, citoquinines, walnut, callus, leaves.

\section{INTRODUCTION}

The common walnut (Juglans regia L.) is a species of global importance owing to its use for wood and fruit (Scaltsoyiannes et al., 1997). However, because of the difficulty of rooting the species from cuttings, production of selected walnut plants has been limited to grafting genotypes of interest (Günes, 1999; Reverberi et al., 2001). Alternatively, the micropropagation of adult walnut individuals is feasible through the cultivation of nodal segments and meristems (Heile-Sudholt et al., 1986; Navatel and Bourrain, 1999), although the method presents a low rate of in vitro proliferation (Marques and Dias, 1995). An alternative to obtain the organogenesis in hardwood cuttings is indirect induction, with which high rates of proliferation of adult matter have been obtained, since it involves induction of callus prior to manifestations of adventitious shoots. This supposes a process of acclimatization of the tissue to in

${ }^{1}$ Universidad de Concepción, Facultad de Ciencias Forestales, Centro de Biotecnología, Victoria 631, Concepción, Chile. *Corresponding author (faaviles@udec.cl).

Received: 06 October 2008.

Accepted: 08 January 2009. vitro conditions before beginning to produce caulinary structures capable of taking root and becoming a plant (Sánchez-Olate et al., 2002). Indirect organogenesis in $J$. regia has been achieved from seeds (Fátima et al., 2006), but has not been reported in tissue from adult material. However, there are reports of the use of the technique with mature tissue (Caboni et al., 2000; Vengadesan et al., 2000) of other woody species, such as apple (Malus domestica Borkh.) and acacia (Acacia sinuata (Lour.) Merr.).

The cultivation of calli can express morphogenic routes oriented to both organogenesis and somatic embryogenesis (Manjkhola et al., 2005). In both cases, nevertheless, callogenic initiation implies an initial stage of differentiation from the parental tissue. Thus, to establish calli cultures, the determination of the initial tissue used is a fundamental factor in order to achieve the desired response (Bandyopadhyay et al., 1999). Zygotic embryos (Kvaalen et al., 2005), hypocotyls (Ahn et al., 2007), cotyledons (Gómez et al., 2006), nuclei (Cardoza and D'Souza, 2002), anthers (Koleva-Gudeva et al., 2007), ovaries and ovules (Sauer and Wilhelm, 2005), petiole and roots (Geneve, 2005), internodes (Chandra and Bhanja, 2002) and leaves (Ainsley et al., 2000) have been used in induction of callogenesis. Leaves are 
of interest in that they allow for the mass production of selected individuals in their adult stage (Leslie et al., 1995).

One of the most influential factors in the morphogenic response associated with calli culture is the type and concentration of growth regulators. Fernández et al. (2000) evaluated different concentrations of growth regulators in material from seeds of $J$. regia, but did not obtain manifestations of structures at the macro-morphological level. In this respect, preliminary research by our working group established that with $21.4 \mu \mathrm{M}$ of naphtalenacetic acid (NAA) and $8.8 \mu \mathrm{M}$ of 6-bencilaminopurine (BAP), the tissues from adult leaves of Juglans regia respond positively to callogenesis, reaching the lowest rate of browning (data not published).

Another important aspect for obtaining an adequate morphogenic response is the culture media used (Ainsley et al., 2000). The use of diverse nutritive media has been reported for culturing calli, with positive results in woody plants. Vengadesan et al. (2000) used MS (Murashige and Skoog, 1962) for callogenesis and subsequent organogenesis of A. sinuata; as did Corredoira et al. (2003) in the callogenesis and somatic embryogenesis based on leaves of chestnut Castanea sativa Mill. Other widely used media with woody plants are the Broad Leaf Medium (BTM) (Chalupa, 1981) and the Woody Plant (WPM) (Lloyd and McCown, 1980). The medium most used with walnut is the Driver Kuniyuki Walnut (DKW) (Driver and Kuniyuki, 1984). However, this culture medium is optimized for culturing nodal segments of the hybrid Paradox (Juglans regia $\mathrm{x}$ J. hindsii) and we found no reports on its effects on walnut callogenesis.

Thus, considering that callogenic induction based on leaves can be one of the best alternatives for cloning and mass producing valuable walnut genotypes, the objective of this work was to analyze and morphologically characterize the type of calli obtained from adult walnut leaves with different culture media.

\section{MATERIALS AND METHODS}

\section{Plant material}

The plant material used was collected from 2-yearold walnut plants grafted with cv. Chandler on patterns of cv. Serr. The grafted plants were kept under greenhouse conditions throughout the duration of the experiment with the aim of collecting material under controlled sanitary conditions on an ongoing basis. Leaves were obtained 3 to 4 weeks after sprouting. The leaves were washed for $10 \mathrm{~min}$ in an ethanol solution at $20 \% \mathrm{v} / \mathrm{v}$, followed by washing in sterile distilled water to disinfect the surface of the collected material. Subsequently, the material was submitted to washing for $10 \mathrm{~min}$ in a solution of sodium hypochlorite $\left(1 \mathrm{~g} \mathrm{~L}^{-1}\right)$, after which the leaves were washed three times in sterile distilled water for 5, 10 and $15 \mathrm{~min}$, respectively.

\section{In vitro establishment}

After disinfection, the leaves were cut into sections of $1 \times 1 \mathrm{~cm}$ and placed with the adaxial surface in contact with the media. All the treatments were maintained in darkness for 4 weeks.

The culture media evaluated were DKW (Driver and Kuniyuki, 1984), WPM (Lloyd and McCown, 1980), MS (Murashige and Skoog, 1962) and BTM (Chalupa, 1981). The composition of each culture medium used is shown in Table 1. All the reactives used in the preparation of the nutritive media had a $99.99 \%$ level of purity. The culture media for all the treatments were supplemented with $21.4 \mu \mathrm{M}$ of naphtalenacetic acid (NAA) and 8.8 $\mu \mathrm{M}$ of 6-bencilaminopurine (BAP), sucrose $\left(30 \mathrm{~g} \mathrm{~L}^{-1}\right)$, polyvinylpolypyrrolidone $\left(1 \mathrm{~g} \mathrm{~L}^{-1}\right)$ and were gelled with $2.5 \mathrm{~g} \mathrm{~L}^{-1}$ of Phytagel (Sigma ${ }^{\circledR}$, Saint Louis, Missouri, USA). Before adding the gellifying agent, $\mathrm{pH}$ was adjusted to 5.8 and sterilized in an autoclave at $120^{\circ} \mathrm{C}$ and $9 ; 8 \times 10 \mathrm{kPa}$ for $20 \mathrm{~min}$. Finally, the media were placed in sterile Petri dishes in a laminar flow chamber.

\section{Data analysis}

A completely random design was used for the data analysis. The treatments were the media BTM, DKW, MS and WPM.

The experiment unit was a Petri dish with six portions of leaves in each. Each treatment was composed of seven experimental units. The analysis applied to the quantitative variables was carried out with Statistica 6.0 software (Hill and Lewicki, 2006). The mean differences among the treatments were analyzed with the Tukey test $(\alpha=0.05)$. The Kruskall-Wallis test (Breslow, 1970) was applied in the cases that did not comply with the suppositions of normality or homogeneity of variance.

The percentages of callogenesis and of nodular calli were evaluated at 4 weeks. The latter was measured in terms of the number of masses per dish that presented nodular formations. As well, the calli were evaluated qualitatively in terms of color (white, yellowish, brownish) and consistency (friable or compact).

\section{Histology}

Histological cuts were made in calli obtained in each of the previously described media. Pieces of calli were fixed in a solution of formaldehyde/acetic acid/ethanol (FAA) for 3 days to be used for the histological cuts. The callus were then dehydrated in a series of gradations of ethanol $\left(50^{\circ}, 60^{\circ}, 70^{\circ}, 80^{\circ}\right.$ and $\left.90^{\circ}\right)$, the cuts were kept in each solution for $2 \mathrm{~h}$. Following this, they were washed 
Table 1. Composition of tissue culture media used in callogenesis of walnut leaf explants.

\begin{tabular}{|c|c|c|c|}
\hline \multirow[b]{2}{*}{ Nutrient } & \multicolumn{3}{|c|}{ Culture media } \\
\hline & MS & DKW & \\
\hline & & $\mathrm{g} \mathrm{dL}^{-1}$ & \\
\hline \multicolumn{4}{|l|}{ Macronutrients } \\
\hline $\mathrm{NH}_{4} \mathrm{NO}_{3}$ & 1.650 & 1.416 & 0.165 \\
\hline$\left(\mathrm{NH}_{4}\right)_{2} \mathrm{SO}_{4}$ & - & - & 0.240 \\
\hline $\mathrm{CaCl}_{2}$ & 0.326 & 0.109 & 0.0326 \\
\hline $\mathrm{Ca}\left(\mathrm{NO}_{3}\right) \times 4 \mathrm{H}_{2} \mathrm{O}$ & - & 1.960 & 0.640 \\
\hline $\mathrm{KH}_{2} \mathrm{PO}_{4}$ & 0.170 & 0.258 & 0.170 \\
\hline $\mathrm{K}_{2} \mathrm{SO}_{4}$ & - & 1.560 & 0.860 \\
\hline $\mathrm{KNO}_{3}$ & 1.9 & - & 0.190 \\
\hline $\mathrm{MgSO}_{4}$ & 0.1805 & 0.383 & 0.1805 \\
\hline \multicolumn{4}{|l|}{ Micronutrients } \\
\hline $\mathrm{H}_{3} \mathrm{BO}_{3}$ & 0.0062 & 0.0124 & 0.0062 \\
\hline $\mathrm{CuSO}_{4} \times 5 \mathrm{H}_{2} \mathrm{O}$ & $2.5 \times 10^{-5}$ & $5 \times 10^{-5}$ & $2.5 \times 10^{-4}$ \\
\hline $\mathrm{MnSO}_{4} \times \mathrm{H}_{2} \mathrm{O}$ & 0.0169 & 0.032 & 0.0169 \\
\hline $\mathrm{Na}_{2} \mathrm{MoO}_{4} \times 2 \mathrm{H}_{2} \mathrm{O}$ & $2.5 \times 10^{-5}$ & $5 \times 10^{-4}$ & $2.5 \times 10^{-4}$ \\
\hline $\mathrm{ZnSO}_{4} \times 7 \mathrm{H}_{2} \mathrm{O}$ & 0.0086 & 0.0212 & 0.0086 \\
\hline $\mathrm{KI}$ & 0.00083 & 0.0016 & 0.00015 \\
\hline $\mathrm{CoCl}_{2} \times 6 \mathrm{H}_{2} \mathrm{O}$ & $2.5 \times 10^{-5}$ & $5 \times 10^{-5}$ & $2 \times 10^{-5}$ \\
\hline $\mathrm{FeSO}_{4} \mathrm{Na}$ EDTA & 0.0367 & 0.0367 & 0.0367 \\
\hline \multicolumn{4}{|l|}{ Amino acids } \\
\hline Glycine & 0.002 & 0.001 & - \\
\hline Cysteine & - & 0.001 & - \\
\hline \multicolumn{4}{|l|}{ Vitamins } \\
\hline Nicotinic acid & 0.0005 & 0.001 & - \\
\hline Thiamine $\mathrm{HCl}$ & 0.0004 & 0.001 & - \\
\hline Pyridoxine & 0.0005 & 0.001 & - \\
\hline $\mathrm{Ca}$ Pantothenate & - & 0.001 & - \\
\hline Biotin & - & $1 \times 10^{-6}$ & - \\
\hline Mioinositol & 0.1 & 0.1 & - \\
\hline
\end{tabular}

Adapted from Murashige and Skoog (1962); Driver and Kuniyuki (1984); Chalupa (1981); and Lloyd and McCown (1980). MS: Murashige and Skoog, DKW: Driver Kuniyuki Walnut, BTM: Broadleaf Tree, WPM: Woody Plant.

in ethanol:benzol in solutions of 3:1, 1:1, 1:3 for $30 \mathrm{~min}$ each. Subsequently, they were washed twice with pure benzol for 30 and $10 \mathrm{~min}$, respectively, before immersion in paraffin. Cuts were obtained with a thickness of 10 $\mu \mathrm{m}$, which were subsequently dried in a stove at $60^{\circ} \mathrm{C}$. Finally, the histological cuts were stained with SafraninFast Green (Johansen, 1940).

\section{RESULTS AND DISCUSSION}

The beginning of callogenesis was observed around the central ribbing in all the media. The percentage of calli was not significantly different among the analyzed treatments. All the treatments produced averages of callogenesis higher than $60 \%$ (Figure 1), demonstrating that the leaf segments respond positively to the induction treatments. These data coincide with those of Vahdati et al. (2006) in the evaluation of callogenesis in leaves and petioles of J. regia, however, these authors did not use NAA as an auxinic agent without 2,4-dichlorophenoxyacetic acid (2,4-D).

There was formation of calli in the MS and DKW media approximately 1 week before any formation in the BTM and WPM media. However, this reactivity in the formation of calli is not always associated with a specific morphogenic response. For example, Tang et al. (2002) point out that the organogenic response in sour cherry (Prunus cerasus L.) and wild cherry (Prunus avium L.) 


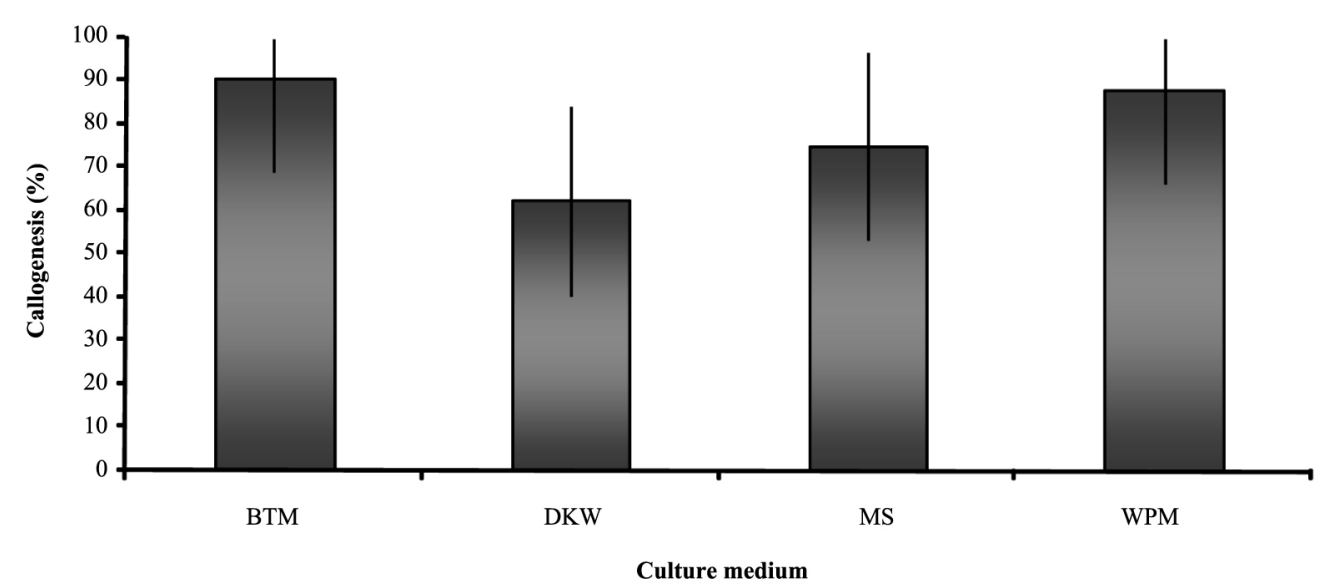

Bar: standard error $(\alpha=0.05)$. BTM: Broadleaf Tree, DKW: Driver Kuniyuki Walnut, MS: Murashige and Skoog, WPM: Woody Plant.

Figure 1. Callogenesis percentage from walnut leaf explants in different culture media.

presented areas with low development of calli in which a large amount of oxidization could be observed. According to Dan (2008) the oxidation is due to the presence of free radicals in the tissue, which are associated with a determined morphogenic response, such that certain types of oxidative agents favor these responses, while others have negative effects on tissue differentiation and favor the production of calli. The latter could explain the absence of differentiation of more reactive calli, in this case of the MS and DKW media, which presented rapid growth but without tissue organization toward the formation of meristems. In this manner, the culture media that favor the growth of callus masses can be recommended in the cellular proliferation stage, while media that present tissue differentiation could be favorable in the process of morphogenic expression.

The aspect of the calli presented differences in terms of color and consistency depending on the nutritive medium from which they originated. In the DKW media the calli were abundant, compact and brownish-yellow in color (Figure 2a). In the MS medium, the calli has a more friable aspect and with less browning (Figure 2b). In the BTM (Figure 2c) and WPM media (Figure 2d) the calli presented a nodular aspect; while only in the WPM media did the calli present a greater degree of browning.

The appearance of calli is an important aspect in research on callogenic cultures and the associated morphogenic response. In the case of somatic embryogenesis based on leaves of $C$. sativa, it has been observed that the embryonic response is closely associated with nodular calli (Corredoira et al., 2003); although Giovanelli et al. (2004) also associated the morphogenic response, expressed in adventitious shoots, with nodular areas in chestnut cotyledons. In calli from leaves of Quercus suber L., friable calli do not present a morphogenic response, which is only evidenced in callus with a compact aspect (Pinto et al., 2002). In the present study, the calli produced in different culture medium, while they presented differences in terms of consistency and color, did not show observable morphogenic responses at the macromorphological level.

It has been observed in species of the Eucalyptus genus that calli with morphogenic capacity vary their aspect depending on the species. Thus, in E. nitens, accelerated cell division induced by hormonal treatments produced caulogenesis in compact calli; while in $E$. globulus, caulogenesis is produced from nodular calli (Bandyopadhyay et al., 1999). Likewise, indirect embrygenesis often occurs based on friable calli produced from leaf segments and stems of Quercus robur L. (Cuenca et al., 1999).

In the histological aspect, the calli produced in the DKW and MS media (Figure 3a) did not show signs of differentiation. On the other hand, while the calli produced in the WPM medium did not present sign of meristem organization, they did show areas of high cellular division in the periphery of the tissue, although without evidence of an organized meristem (Figure $3 b$ ). The calli produced in the BTM media presented areas of differentiation within the calli, in which the first stages of tissue organization were observed (Figure 3c), although these structures did not manifest themselves at the surface of the masses. In this case, it is possible to observe meristemoids in different directions, some meristem sections being transversal (Figure 3d, solid arrow) and others longitudinal (Figure 3d, segmented arrows). 


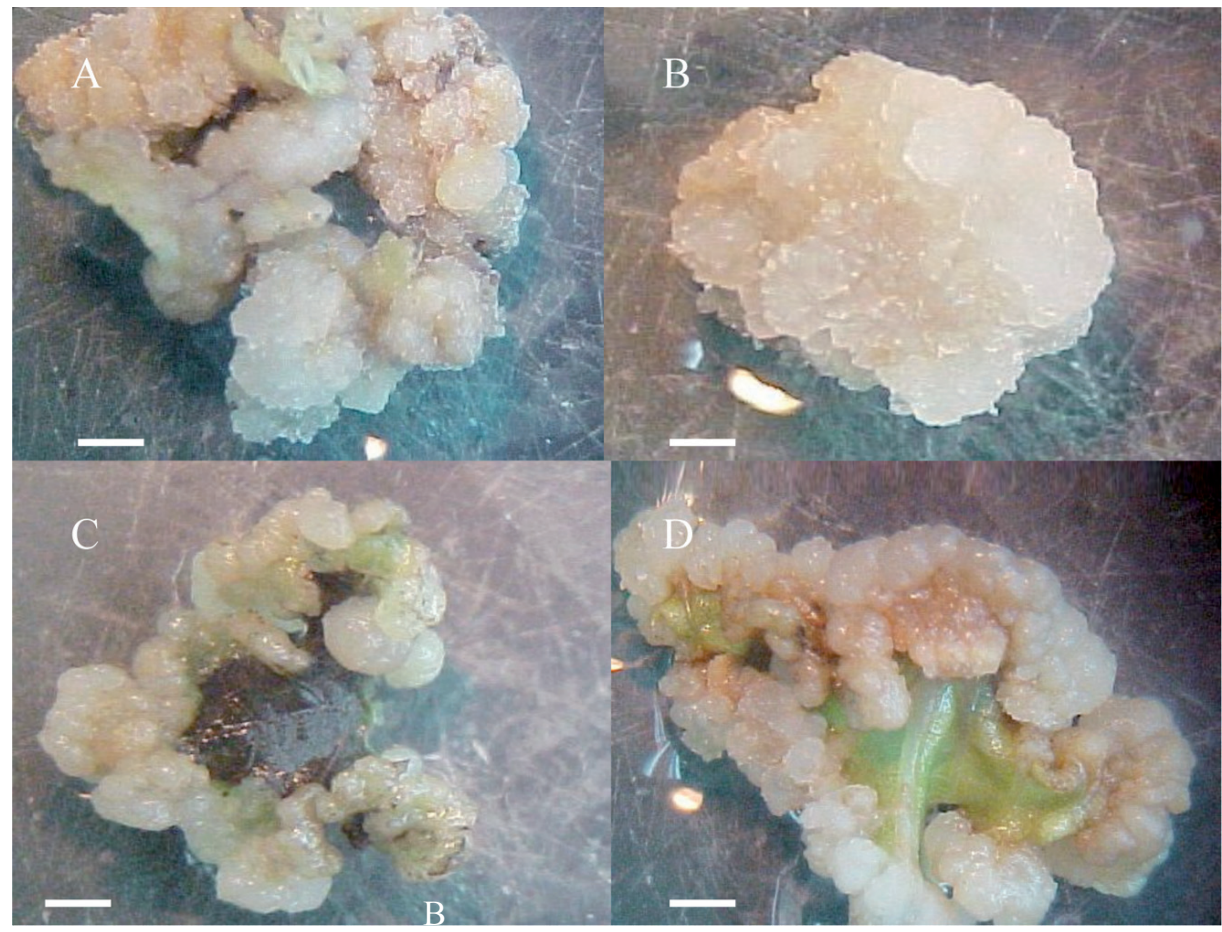

Bars $=0.25 \mathrm{~cm}$.

Figure 2. Callogenesis from walnut leaf explants. Callus produced in media (A) Driver and Kuniyuki Walnut; (B) Murashige and Skoog; (C) Broadleaves Tree; and (D) Woody plant.

The BTM and WPM medium presented a higher proportion of nodular calli than the MS and DKW medium (Figure 4). This could be because the BTM and WPM have lower concentrations of macronutrients than the DKW and MS media, in particular, lower concentrations of $\mathrm{Ca}$ and $\mathrm{N}$ (Table 1). The composition of the culture media has an important influence on the morphogenic response, as was demonstrated in the numerous investigations gathered by Pierik (1990), given that the morphogenic response of a determined tissue is associated with the mineral nutrition that is applied. It is even possible to eliminate growth regulators by modifying the mineral composition of the culture medium (Ramage and Williams, 2002).

In the formation of adventitious shoots from in vitro cultivated wild and sour cherries, Tang et al. (2002) established that high concentrations of $\mathrm{N}$ in the culture media are associated with lower levels of regeneration of adventitious shoots, with the WPM media presenting the highest percentages of regeneration, while the DKW media did not produce an organogenic response, possibly because of the higher level of inorganic $\mathrm{N}$ compared to the previous media.

Although several investigations have compared the embryonic or organogenic potential of calli produced in different culture media, there has not been a general standard for all the vegetal species. For example, evaluating different nutritive medium in calli cultures from leaf segments of Morus indica L. it was found that the MS media does not produce callogenesis (Sahoo et al., 1997); Nevertheless, in studies with adult leaves of Paulownia elongata S., Y. Hu obtained a higher proportion of callus with morphogenic response in the MS media than in the WPM media (Castellanos et al., 2006). In this manner, the most appropriate culture media for a determined response depends, among other factors, on the species.

Although these results establish that the calli with better morphogenic characteristics in terms of tissue organization originate from the BTM culture media, it is still necessary to obtain a manifestation of these structures in formation at the surface level, which is associated with, among other factors, the induction time, the type and concentration of growth regulators, genotype and the type and source of carbohydrates (Scaltsoyiannes, 1997; Fernández et al., 2000; Iraqi and Tremblay, 2001). In other species, such as Olea europaea L. and Decalepis hamiltonii Wight \& Arn, it has been established that a manifestation stage is necessary posterior to the callogenic induction stage, in which one or more components of the media are modified, and it is in this stage that it is possible to differentiate the calli that is obtained in induction (Shibli et al., 2001; Giridhar et al., 2004; Bunn et al., 2005). 


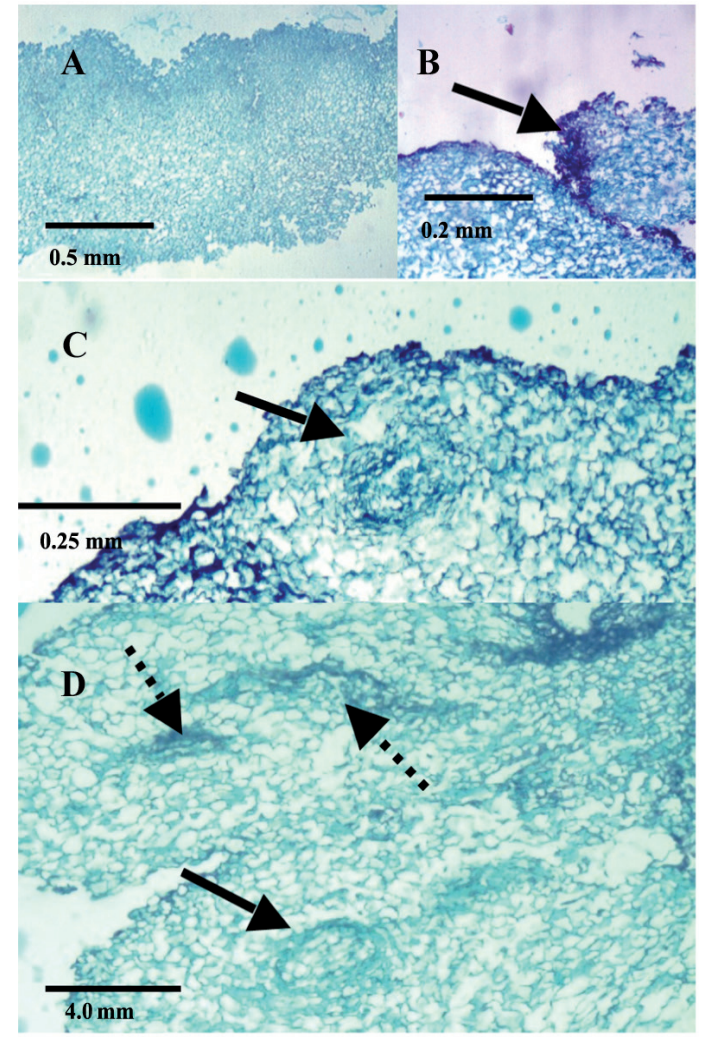

Arrows show meristem initiation (solid arrow: transversal section; segmented arrow: tangential section).

Figure 3. Histology from callus produced in culture media: (A) Murashige and Skoog; (B) Woody plant; (C) and (D) Broadleaf Tree.
While the results obtained in this study do not show morphogenic responses at the macromorphological level, they do establish the bases for differentiating callus developed from leaf segments of $J$. regia, and should be used as a base for future studies on the morphogenesis of adult matter of $J$. regia.

\section{CONCLUSIONS}

The culture medium influences the morphogenetic characteristics of the calli resulting from Juglans regia L. cv. Chandler. The calli induced in the BTM media presented the strongest morphogenic potential, with meristemoids in their first state of organization.

\section{ACKNOWLEDGEMENTS}

The authors wish to thank the Forest Pathology Laboratory for the use of their equipment. In particular, we thank Alejandra Brieva for her cooperation. As well, Fabiola Avilés wishes to thank CONICYT for the scholarship provided to carry out her studies for a Doctorate in Forestry Sciences at the Universidad de Concepción.

\section{RESUMEN}

Efecto del medio de cultivo en la callogénesis de nogal (Juglans regia L.) a partir de hojas adultas. Con el objeto de definir aspectos preliminares de la callogénesis de nogal (Juglans regia L.), para establecer sistemas de

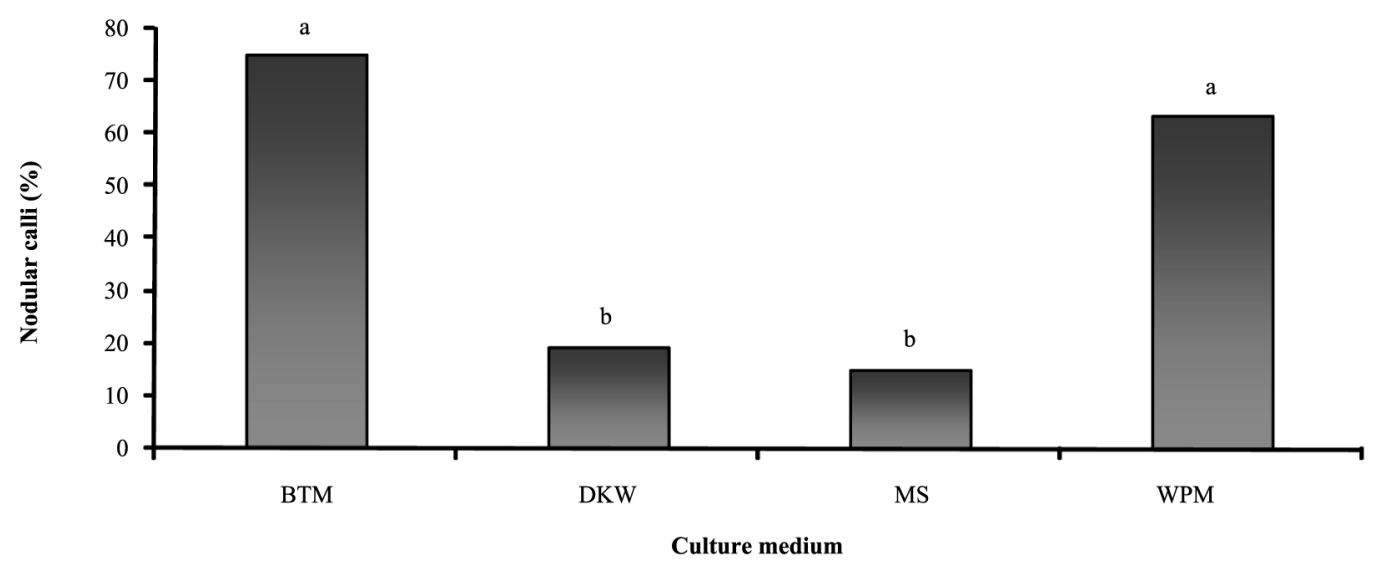

Different letters indicate significant differences $(\alpha \leq 0.05)$. BTM: Broadleaf Tree, DKW: Driver Kuniyuki Walnut, MS: Murashige and Skoog, WPM: Woody Plant.

Figure 4. Nodular callus percentage from walnut leaf explants in different culture media. 
propagación vegetativa vía indirecta, este trabajo analizó la inducción callogénica en hojas adultas de nogal, utilizando los medios de cultivo broadleaves tree (BTM), Murashige y Skoog (MS), Driver Kuniyuki Walnut (DKW) y Woody Plant (WPM). Segmentos foliares de $1 \mathrm{~cm}^{2}$ previamente esterilizados fueron puestos en cada medio de cultivo suplementado con $21,4 \mu \mathrm{M}$ de ácido naftalén acético (ANA) y $8,8 \mu \mathrm{M}$ de 6-bencilaminopurina (BAP). Se utilizó un diseño completamente aleatorio, la unidad experimental correspondió a una placa Petri con seis segmentos foliares. Cada tratamiento estuvo compuesto por siete repeticiones. A las 4 semanas de cultivo se evaluó la callogénesis (\%), callos nodulares (\%), e histología de macizos callosos, para lo cual se obtuvieron cortes de $10 \mu \mathrm{m}$ que se tiñeron con safraninafastgreen. No se registraron diferencias significativas en la inducción de callogénesis entre los medios evaluados ( $\alpha=0,05)$; pero el porcentaje de callos nodulares fue significativamente mayor en los medios BTM (75\%) y WPM (63\%). Sólo en el medio BTM la histología mostró presencia de zonas meristemáticas en el interior del macizo, sin que se observara expresión externa de dichas formaciones. Estos resultados indican que el medio de cultivo influye en las características morfogénicas del callo resultante, siendo los callos inducidos en el medio BTM los de mayor potencial morfogénico, al observarse meristemoides en sus primeros estadíos de organización.

Palabras clave: auxinas, citoquininas, nogal, callo, hojas.

\section{LITERATURE CITED}

Ahn, Y., L. Vang, T. McKeon, and G. Chen. 2007. Highfrequency plant regeneration through adventitious shoot formation in castor (Ricinus communis L.) In Vitro Cell. Dev. Biol.-Plant 43:9-15.

Ainsley, P., G. Collins, and M. Sedgley. 2000. Adventitious shoot regeneration from leaf explants of almond Prunus dulcis Mill. In Vitro Cell. Dev. Biol.-Plant 36:470-474.

Bandyopadhyay, S., K. Cane, G. Rasmussen, and J. Hamill. 1999. Efficient plant regeneration from seedling explants of two commercially important temperate eucalypt species-Eucalyptus nitens and $E$. globulus. Plant Sci. 140:189-198.

Breslow, N. 1970. Ageneralized Kruskall-Wallis test for comparing $\mathrm{K}$ samples subject to unequal patterns of censorship. Biometrika 57:579-594.

Bunn, E., T. Seraratna, K. Sivasithamparam, and K.W. Dixon. 2005. In vitro propagation of Eucalyptus phylaxis L. Johnson and K. Hill., a critically endangered relic form Western Australia. In Vitro Cell. Dev. Biol.-Plant 41:812-815.
Caboni, E., P. Lauri, and S. D’ Angeli. 2000. In vitro plant regeneration from callus of shoot apices in apple shoot culture. Plant Cell Rep. 19:755-760.

Cardoza, V., and L. D'Souza. 2002. Induction, development and germination of somatic embryos from nucellar tissues of cashew (Anarcadium occidentale L.). Sci. Hortic. (Canterbury, Engl.) 93:367-372.

Castellanos, O., A. Rodriguez, J. Rodríguez, y B. Rodríguez. 2006. Organogénesis indirecta y enraizamiento in vitro de Paulownia elongata. e-Gnosis (on-line). Vol 4, Art. 15.

Chalupa, V. 1981. Micropropagation of conifer and broadleaved forest trees. Commun. Inst. For. Czechosl. 13:7-39.

Chandra, I., and P. Bhanja. 2002. Study of organogenesis in vitro from callus tissue of Flacurtia jangomonas (Lour.) Raeush through scanning electron microscopy. Curr. Sci. 83:476-479.

Corredoira, E., A. Ballester, and A.M. Vieitez. 2003. Proliferation, maturation and germination of Castanea sativa Mill. somatic embryos originated from leaf explants. Ann. Bot. (London) 92:120-136.

Cuenca, B., M.C. San José, M.T. Martínez, A. Ballester, and A.M. Vieitez. 1999. Somatic embriogenesis from steam and leaf explants of Quercus robur L. Plant Cell Rep. 18:538-543.

Dan, Y. 2008. Biological functions of antioxidants in plant transformation. In Vitro Cell. Dev. Biol.-Plant 44:149161.

Driver, J., and A. Kuniyuki. 1984. In vitro propagation of Paradox walnut rootstock. HortScience 19:507-509.

Fatima, A., A.N. Kamili, and A.M. Shah. 2006. Plantlet regeneration from excised embryonal axes, shoot apices and nodal segments of Juglans regia L. Acta Hort. (ISHS) 705:387-392.

Fernández, H., C. Pérez, and R. Sánchez-Tamés. 2000. Modulation of the morphogenic potential of the embryonic axis of Juglans regia by cultural conditions. Plant Growth Regul. 30:125-131.

Geneve, R.2005. Comparative adventitious shootinduction in Kentucky coffee tree root and petiole explants treated with thidiazuron and benzilaminopurine. In Vitro Cell. Dev. Biol.-Plant 41:489-493.

Giovanelli, A., R. Gianni, A. Bennicci, and B. Mori. 2004. In vitro organogenesis of chestnut (Castanea sativa Mill.) cotyledon explants; responses to growth regulators and developmental aspects. In Vitro Cell. Dev. Biol.-Plant 40:509-514.

Giridhar, P., V. Kumar, and G.A. Ravishankar. 2004. Somatic embryogenesis, organogenesis, and regeneration from leaf callus culture from Decalepis hamiltonii Wight \& Arn., an endangered shrub. In Vitro Cell. Dev. Biol.-Plant 40:567-571. 
Gómez, C., M. Uribe, D. Ríos, y M. Sánchez-Olate. 2006. Inducción de callo embriogénico en Eucalyptus globulus Labill. Interciencia 31:734-738.

Günes, T. 1999. An investigation on rooting of Juglans regia L. hardwood cuttings. Turk. J. Bot. 23:367-372.

Heile-Sudholt, C., C. Huetteman, J. Preece, J. Van Sambeek, and G. Gaffney. 1986. In vitro embryogenic axis and seedling shoot tip culture of Juglans regia L. Plant Cell Tiss. Organ Cult. 6:189-197.

Hill, T., and P. Lewicki. 2006. Statistic: Method and applications. 830 p. Statsoft, Tulsa, Oklahoma, USA.

Johansen, D.A. 1940. Plant microtechnique. 523 p. Editorial McGraw Hill, London, UK.

Iraqi, D., and F. Tremblay. 2001. Analysis of carbohydrate metabolism enzymes and cellular contents of sugars and proteins during spruce somatic embryogenesis suggests a regulatory role of exogenous sucrose in embryo development. J. Exp. Bot. 52:2301-2311.

Koleva-Gudeva, L., M. Spasenoski, and F. Trajkova. 2007. Somatic embryogenesis in pepper anther culture: The effect of incubation treatments and different media. Sci. Hortic. (Canterbury, Engl.) 111:114-119.

Kvaalen, H., O. Gram Daehlen, A. Tove Rognstad, B. Grónstad, and U. Egertsdotter. 2005. Somatic embryogenesis for plant production of Abies lasiocarpa. Can. J. For. Res. 35:1053-1060.

Leslie, C., G. McGranahan, and M. Mendum. 1995. Genetic engineering of walnut (Juglans regia L.). Acta Hort. (ISHS) 442:33-42.

Lloyd, G., and B. McCown. 1980. Commercially-feasible micropropagation of mountain laurel, Kalmia latifolia by use shoot-tip culture. Int. Plant Prop. Soc. Proc. 30:421-427.

Manjkhola, S., U. Dhar, and M. Joshi. 2005. Organogenesis, embryogenesis and synthetic seed production in Arnebia euchroma an critically endangered medicinal plant of the Himalaya. In Vitro Cell. Dev. Biol.-Plant 41:244-248.

Marques, D., and J. Dias. 1995. In vitro shoot culture on Juglans regia L.: repeated subculturing on juvenile and adult material. Acta Hort. (ISHS) 442:251-256.

Murashige, T., and F. Skoog. 1962. A revised medium for rapid growth and bioassay with tobacco. Physiol. Plant. 15:473-497.

Navatel, J., and L. Bourrain. 1999. Plant production of walnut Juglans regia L. by in vitro multiplication. Acta Hort. (ISHS) 544:465-471.
Pierik, R. 1990. Cultivo in vitro de las plantas superiores. 326 p. Ediciones Mundi-Prensa, Madrid, España.

Pinto, G., H. Valentim, A. Costa, S. Castro, and C. Santos. 2002. Somatic embryogenesis in leaf callus from a mature Quercus suber L. tree. In Vitro Cell. Dev. Biol.-Plant 38:560-572.

Ramage, C., and R. Williams. 2002. Mineral nutrition and plant morfogenesis. In Vitro Cell. Dev. Biol.-Plant 38:116-124.

Reverberi, M., G. Falasca, P. Lauri, E. Caboni, and M.M. Altamura. 2001. Indoleacetic acid induces xylem formation instead rooting in walnut (Juglans regia L.) microcuttings. Plant Biosyst. 135:71-77.

Sahoo, Y., S.K. Pattnaik, and P.K. Chand. 1997. Plant regeneration from callus cultures of Morus indica L. from seedlings and mature plants. Sci. Hortic. (Canterbury, Engl.) 69:85-98.

Sánchez-Olate, M., D. Ríos, M. Revilla, y R. Rodríguez. 2002. Participación de poliaminas endógenas en el desarrollo de injertos y brotes epicórmicos de nogal. Agrociencia 17:215-219.

Sauer, U., and E. Wilhelm. 2005. Somatic embryogenesis from ovaries, developing ovules and immature zygotic embryos, and improved embryo development of Castanea sativa. Biol. Plant. 49:1-6.

Scaltsoyiannes, A., P. Tsoulpha, K.P. Panetsos, and D. Moulalis. 1997. Effect of genotype on micropropagation of walnut trees (Juglans regia). Silvae Genet. 46:326-332.

Shibli, R., M. Shatnawi, Abu-Ein, and K.H. Al-Juboory. 2001. Somatic embryogenesis and plant recovery from callus of 'Nabali' Olive (Olea europea L.). Sci. Hortic. (Canterbury, Engl.) 88:243-256.

Tang, H., Z. Ren, G. Reustle, and G. Krczal. 2002. Plant regeneration from leaves of sweet and sour cherry cultivars. Sci. Hortic. (Canterbury, Engl.) 93:235-244.

Vahdati, K., M. Jariteh, V. Niknam, M. Mirmasoumi, and H. Ebrahimzadeh. 2006. Somatic embryogenesis and embryo maturation in Persian walnut. Acta Hort. (ISHS) 705:199-205.

Vengadesan, G., A. Ganapathi, R. Prem Anand, and V. Ramesh Anbazhagan. 2000. In vitro organogenesis and plant formation in Acacia sinuata. Plant Cell Tiss. Organ Cult. 61:23-28. 